\title{
Design of Solar-Powered Aeration System for Shrimp Ponds of Farmers in Thailand
}

\author{
Arckarakit Chaithanakulwat \\ Department of Electrical Engineering, Dhonburi Rajabhat University, Samut Prakan 10540, Thailand
}

Corresponding Author Email: akharakit.c@dru.ac.th

https://doi.org/10.18280/ejee.210608

Received: 16 June 2019

Accepted: 23 August 2019

\section{Keywords:}

photovoltaic, air pump system, boost converter, life cycle cost, control equipment, aquaculture, hysteresis current band, dissolved oxygen level

\begin{abstract}
In Thailand, shrimp farmers traditionally rely on the electricity supplied by government organization to perform air aeration in their shrimp ponds. This paper designs an affordable solar-powered aeration system for shrimp ponds, which promotes the productivity of Thai shrimp farmers. The aeration system consists of three parts: the control of maximum power point (MPP) tracking, the Z-source DC-DC converter, and battery charging. In the first part, the energy was controlled by algorithms like perturb and observe (P\&O), incremental conductance (INC), fuzzy logic control (FLC) and genetic algorithm (GA). In the second part, a set of devices were designed to regulate the energy to be supplied to the inverter and aerator. In the third part, the battery was charged to support aerator operation at night. Comparative experiments show that the proposed aeration system improved the dissolved oxygen (DO) level in shrimp ponds by 7.48ppm on average from the level of the traditional method, and controlled the mean temperature in shrimp ponds at $30.33^{\circ} \mathrm{C}$, which is favorable for shrimp growth. The research provides a satisfactory green aeration system for shrimp farmers in Thailand.
\end{abstract}

\section{INTRODUCTION}

Over the past decades, shrimp has become an important export product of Thailand. Most shrimp farmers in Thailand live in coastal provinces, and manage small shrimp ponds. In total, there are about 19,150 shrimp farms across the country. $85 \%$ of them are small farms with an area no greater than $16,000 \mathrm{~m}^{2}$. Despite the small scale of individual farms, shrimp farming contributes greatly to rural income and employment [1-2].

Shrimp farming requires lots of electricity to pump water and provide air to the shrimp ponds. Currently, most shrimp farms in Thailand receive electricity from the power grid. However, the electricity on the grid is not green. In 2014, $75.8 \%$ of electricity in Thailand was produced from fossil fuels, while only $20.2 \%$ from renewable energy sources. The solar energy and wind energy have not been fully utilized.

The Thai government has set high goals for renewable energy generation: producing $2 \mathrm{GW}$ of electricity from solar energy and $1.6 \mathrm{GW}$ from wind energy by 2021 [3], and rolled out several policies to encourage the use of solar and wind energy [4]. However, there is no report on solar and wind power systems, and the electricity produced by these systems is difficult to get connected to the grid.

Comparatively, solar energy is the most promising renewable energy source in Thailand. If properly developed, solar power generation could improve the energy security of the country [5]. According to official sources, the installed capacity of solar cells in Thailand amounted to around $3,200 \mathrm{MW}$ in 2017 . $95 \%$ of these solar cells are mounted on the ground, and only 5\% on rooftops. Although the government provides financial incentives to ground-mounted solar cells, the consumers are interested in rooftop solar cells, due to their installation cost and multiple functions. Shrimp farmers are among the most loyal household customers of rooftop solar cells [6].

The popularity of rooftop solar cells also give rise to new problems. The household customers only consume a limited amount of photovoltaics (PV) electricity. In the daytime, a huge amount of surplus PV electricity flows into the grid, causing grid instability [7-8]. To solve the problem, many household customers, especially shrimp farmers, connect a low-cost battery to the rooftop solar cell system [9-10], which saves the surplus electricity for further use. The investment in rooftop solar cells rewards the shrimp farmers economic benefits in a very short time.

Therefore, this paper attempts to design an affordable aeration system for shrimp ponds, aiming to fully utilize the electricity generated by rooftop solar cells. First, the author compared the control of the maximum power point (MPP) tracking based on four algorithms, namely, perturb and observe (P\&O), incremental conductance (INC), fuzzy logic control (FLC) and genetic algorithm (GA). Then, a Z-source DC-DC converter was designed to regulate the energy to be supplied to the inverter and aerator. After that, the battery charging was controlled to reserve electricity for the aerator operations at night. The proposed aeration system can increase the content of dissolved oxygen in shrimp ponds of small farmers, improve the standard and productivity of the ponds, and reduce the electricity cost of the power grid.

\section{DESCRIPTION OF PROPOSED SCHEME}

The electrical production of solar cells has factored and affected many. The intensity of light from the sun temperature and cloud cover instantly is a factor. Causing solar cells to not produce stable and goal electrical energy. The energy 
produced by solar cells is more or less dependent on natural phenomena. The forementioned reason, if there are no circuit and equipment to control, it may cause insufficient electrical power required for use. In this research, the researcher has designed a prototype. The consists of the principle of controlling the maximum power point tracking of solar cells. Using P\&O, INC, FLC and GA algorithms to compare. And find the efficiency to be suitable for the system by using MATLAB/Simulink program.

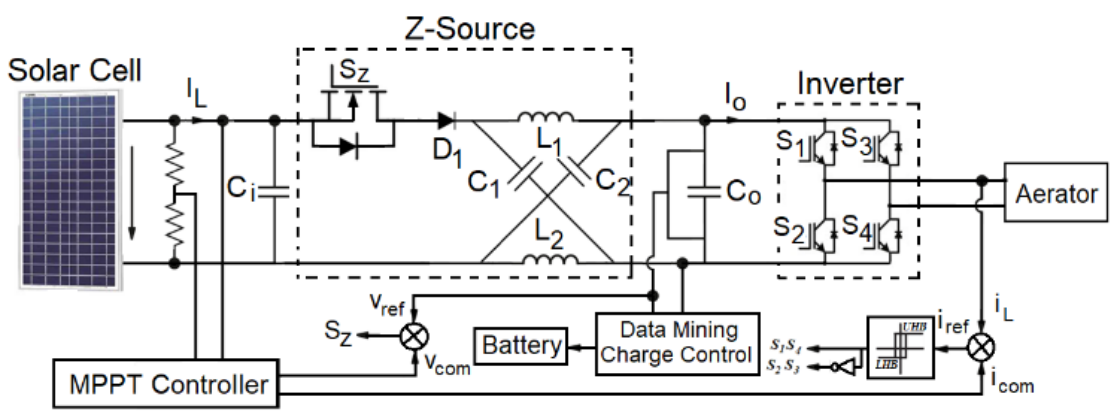

Figure 1. Schematic of the solar-powered aeration system

Considering in Figure 1, the first part, controlling the maximum power point of the solar cell with the comparison algorithm. That was the most efficiency, controlling the switch of the IGBT device. It can be seen that the control will detect the heater current. The chip controls the operation of the inverter to compare with the energy. Obtained from the maximum power point tracking algorithm. The capacitancevoltage drop across the capacitor is low. The operating mechanism of the booster converter circuit will be controlled to the specified voltage. Likewise, if the capacitance-voltage drop across the capacitor is high. The booster converter circuit will regulate the specified voltage. The second part is to charge the battery with the data mining charge controller. The third part tests the achievement and satisfaction of the farmers. Moreover, the relation of the cost and the reliability of the solar aeration system. This research uses the voltage across the capacitor to the charger circuit to control the mechanical inlet charge. Quick charge and control charge automatically. The controlled energy mentioned above is supplied to the inverter. Supplied to the aerator to fill the air in the shrimp ponds of farmers.

\subsection{Mathematical modelling of the solar cell system}

In Figure 2, the general solar cell system can be written as a mathematical model consisting of a single diode device used as a solar cell for a silicon model called photocurrent. Consequently, considering the mathematical model, it is found that the non-linear diode $(D)$ is connected in parallel with the internal resistance $\left(R_{S h}\right)$ and the series with the resistance $\left(R_{S}\right)$ can write the mathematical relationship as:

$$
I=I_{p h}-I_{s}\left[\exp \left(\frac{q\left(V+I R_{s}\right)}{A k T}-1\right)\right]-\frac{V+I R_{s}}{R_{s h}}
$$

where, $I_{p h}$ is photocurrent. $I_{S}$ is the diode saturation current. $q$ is coulomb constant as $1.602 \times 10^{-19} \mathrm{C}$. $k$ is temperature $(K)$. $A$ is a P-N junction ideality factor. $R_{s}$ and $R_{S h}$ are initial series resistance [11]. The photocurrent is the function of solar radiation and cell temperature described as:

$$
I=\left(\frac{S}{S_{r e f}}\right)\left[I_{p h, r e f}+C_{T}\left(T-T_{r e f}\right)\right]
$$

From Eq. (2), $S$ is the real solar radiation $\left(\mathrm{W} / \mathrm{m}^{2}\right) ; S_{r e f}$, is the solar radiation. $T_{r e f}$ is absolute cell temperature. $I_{p h, r e f}$ is photocurrent in standard test conditions respectively. $C_{T}$ is the temperature coefficient $(A / K)$. Also, diode saturation current varies with the cell temperature are expressed as:

$$
I_{S}=I_{S, r e f}\left(\frac{T}{T_{r e f}}\right)^{3} \exp \left[\frac{q E_{g}}{A K}\left(\frac{1}{T_{r e f}}-\frac{1}{T}\right)\right]
$$

where, $I_{S, \text { ref }}$ is the diode saturation current in standard test conditions. $E_{g}$ is the band-gap energy of the cell semiconductor.

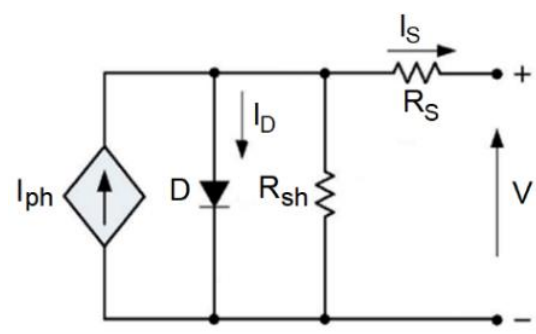

Figure 2. Single-diode mathematical model of a solar cell

Table 1. Standard test condition data

\begin{tabular}{cc}
\hline \multicolumn{2}{c}{ Electrical characteristics } \\
\hline Cell of Type & Polycrystalline silicon \\
Open circuit Voltage $\left(\mathrm{V}_{\mathrm{oc}}\right)$ & $44.70 \mathrm{~V}$ \\
Short circuit current $\left(\mathrm{I}_{\mathrm{sc}}\right)$ & $8.23 \mathrm{~A}$ \\
Maximum Power Voltage $\left(\mathrm{V}_{\mathrm{pm}}\right)$ & $35.60 \mathrm{~V}$ \\
Maximum Power Current $\left(\mathrm{I}_{\mathrm{pm}}\right)$ & $7.72 \mathrm{~A}$ \\
Maximum Power $\left(\mathrm{P}_{\max }\right)$ & $275 \mathrm{~W}$ \\
Series Fuse Rating & $10 \mathrm{~A}$ \\
Type of output terminal & $\mathrm{Junction} \mathrm{Box}$ \\
The temperature coefficient of $\mathrm{I}_{\mathrm{sc}}$ & $\pm 0.0538 \% /{ }^{\circ} \mathrm{C}$ \\
Temperature coefficient of $\mathrm{V}_{\mathrm{oc}}$ & $\pm 0.03321 \% /{ }^{\circ} \mathrm{C}$ \\
The temperature coefficient of Power & $\pm 0.04767 \% /{ }^{\circ} \mathrm{C}$ \\
Temperature range & $-40{ }^{\circ} \mathrm{C}-85^{\circ} \mathrm{C}$ \\
No of cells and connections & $12 \times 6$ in series \\
\hline
\end{tabular}

This research, use solar panels from the manufacturer as per the standard solar cells by the manufacturer according to SHAORISOLAR solar cell Module CRM300S156P-72 
Standard. The I-V characteristic curve of the photovoltaic module under generic temperature and radiation conditions. When the characteristic parameters under standard conditions are known as given Table 1.

\subsection{The MPPT algorithm}

\subsubsection{Perturb and observe algorithm}

The principle of the $\mathrm{P} \& \mathrm{O}$ algorithm causes the energy of the solar cells to change continuously. The energy increases $\left(P_{p v}(k)\right)$ due to the disturbance. Moreover, the disturbance will continue in the same direction. If the energy decreases $\left(P_{p v}(k-\right.$ 1)) immediately after reaching the maximum power point $\left(P_{p v}\right)$ harassment will occur newly. The principle of this algorithm can be easily explained by the flow chart as in Figure 3.

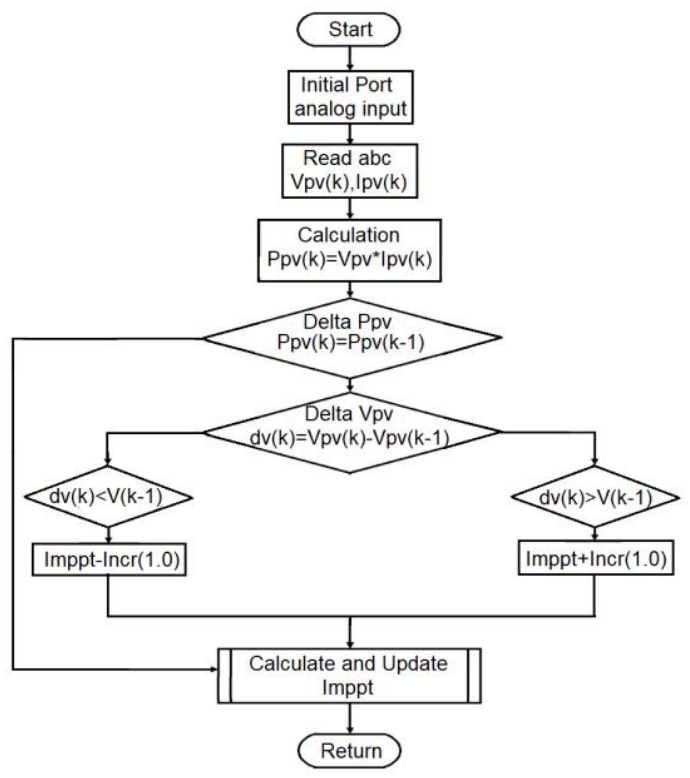

Figure 3. $\mathrm{P} \& \mathrm{O}$ algorithm

\subsubsection{Incremental conductance (INC) algorithm}

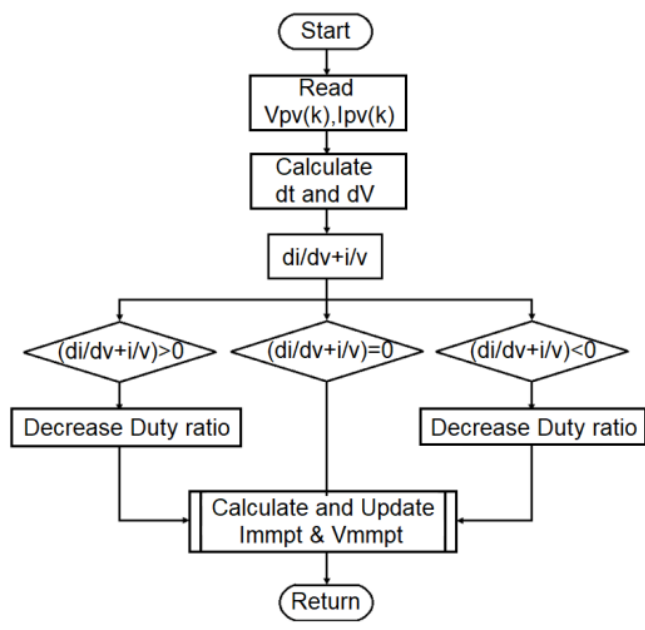

Figure 4. INC algorithm

INC is a way to overcome the disadvantages of interference. Observation methods for maximum power tracking under rapid change. This method can check MPPT at the point of MPP $(d i / d v+i / v=0)$. It does not meet the MPPT condition is recalculated using the relationship between $\mathrm{di} / \mathrm{dv}$ and $\mathrm{i} / \mathrm{v}$. This relationship is caused by $\mathrm{dp} / \mathrm{dv}$ being negative. When MPPT is on the right side of MPP $(d i / d v+i / v<0)$ and positive when on the left of MPP $(d i / d v+i / v>0)$. These incentives are able to track the increase in $\mathrm{P} \& \mathrm{O}$ more quickly. There is a disadvantage it is more complicated compared to $\mathrm{P} \& \mathrm{O}$. Moreover, the algorithm can be explained more easily by using the flow chart as in Figure 4.

\subsubsection{Fuzzy logic control algorithm}

MPPT that uses fuzzy logic control. Can get many of the advantages of better performance, strong and simple design. Also, this technique does not must knowledge of the exact format of the system. The proposed system input variable of the FLC is the maximum power change in PV. The consisting of delta $V_{P V}(k)$ and delta $I_{P V}(k)$ change. While the output of the FLC is the size of the maximum or decreasing maximum power change. Can be explained by using the flow chart as in Figure 5.

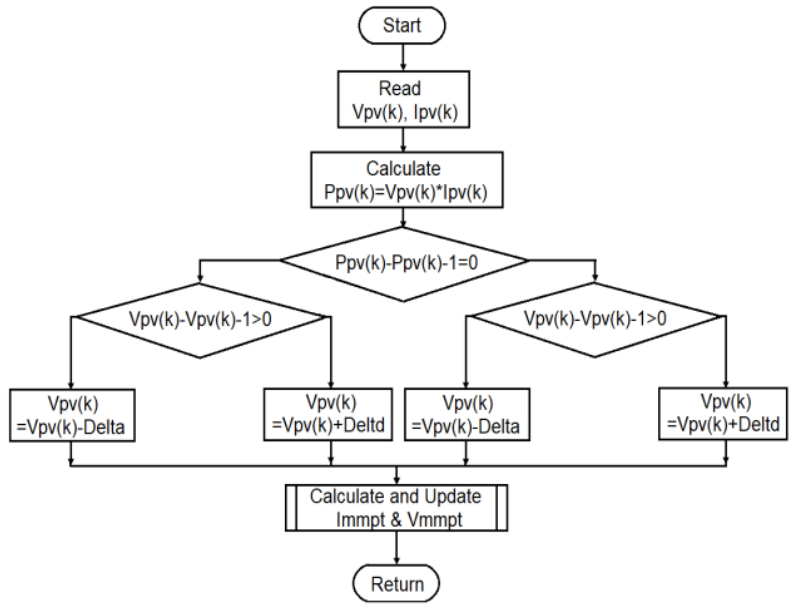

Figure 5. FLC algorithm

\subsubsection{Genetic algorithm (GA)}

The MPPT algorithm based on the genetic algorithm (GA).

An optimal system is similar to natural genetics. Using this method, the best set of $V_{p v}(k)$ and $I_{p v}(k)$ parameters. Determined based on "survival of the most appropriate principles". But in reality, there are three basic operators involved in GA step searches $P_{p v}(k), V_{p v}(k)$ and $I_{p v}(k)$. That cause changes in the maximum or decreased maximum power capacity can be explained. The flow chart as in Figure 6 .

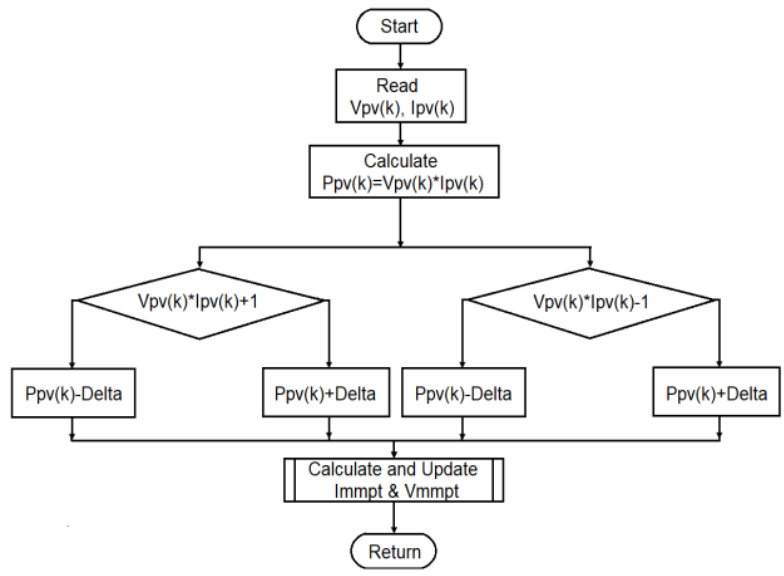

Figure 6. GA algorithm 


\subsection{Z-source DC-DC converter}

The concept of Z-source can be used directly, ac-ac power conversion. It can also be used for dc-dc power conversion. Zsource DC-DC is the converter topology used control relationship between input and output. Figure 7 (a) shows the proposed Z-source dc-dc operation, divided into two modes. The consisting of the voltage-source mode and the currentsource mode. The first mode is the DC voltage-source as shown in Figure 7 (b). The second mode is DC current source as shown in Figure 7 (c), both modes use two switches $\left(S_{l}\right.$ or $S_{2}$ ). Each switch can be assembled with a power transistor and a parallel resistor. The freewheeling diode allows current to flow in two directions miniature. The inductors and capacitors are used for filtering [12].

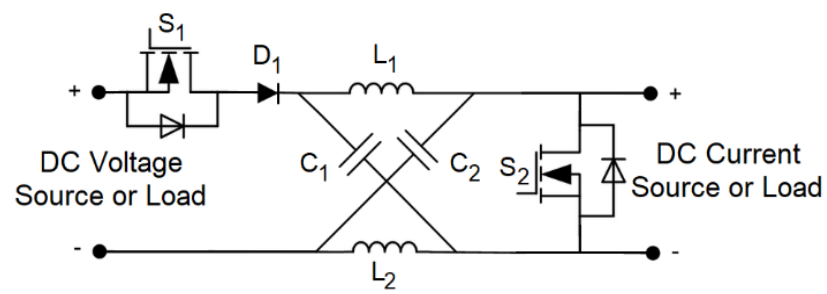

(a) Z-source DC-DC converter topology

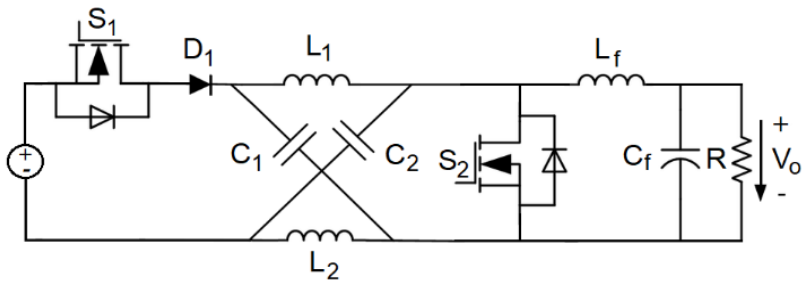

(b) DC voltage-source

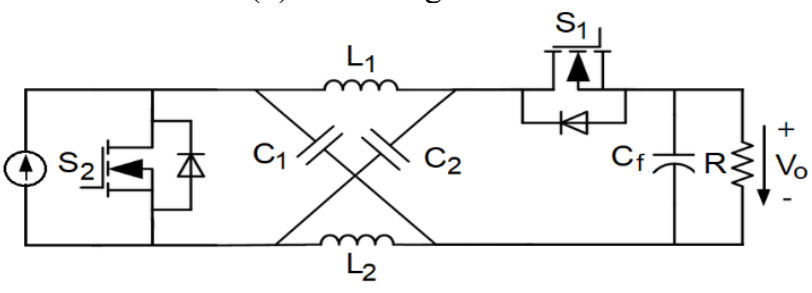

(c) DC current-source

Figure 7. Two operating modes of Z-source DC-DC converter

Based on Figure 7, Z-source DC-DC converter, in general, users tend to consider the coordinates of the parameters and capabilities of the device so that it can control the voltage and current for the desired purpose. Principles and methods of control often control the switch of the device by controlling the operation of the PWM signal. Nevertheless, using the traditional and the new Z-source DC-DC converter, users have to consider the design of the device so that it can handle high voltages. The devices that should be considered include switching devices, inductors, capacitors, and more importantly, the load resistance connected to the Z-source DC-DC converter. Consequently, the DC-DC Z-source converter presented in this research will design the three devices are suitable for the inverter and correspond to the input voltage from the solar cell to control the voltage to be stable.

\subsection{Hysteresis current control}

The method hysteresis current control is generating the desired pulse by comparing. The signal with the histogram to control the source voltage inverter. A controlling switch of the inverter, the asynchronous voltage supply to slope the current through. The inductor up and down to meet the reference current. Current control hysteresis is the easiest method used for real-time control. Figure 8, shows the ripple of the current between two limits. The upper limit of hysteresis is the sum of the reference currents. The maximum error or show the ripple of the hysteresis current between the two limits. The upper limit is the sum of the reference currents and the difference between the upper limit. The reference current for the lower histories. It is the subtraction of the reference current and the minimum error. The configuration for minimum and maximum errors should be the same. Resulting in hysteresis bandwidth equal to double the error. The operation principle of the inverter. The output voltage of each phase is essential to the switching pulse of each leg. As a result, make the gate switching for the active power filter received. The voltage drops across the inductor. The frequency of switching and frequency changed by adjusting the bandwidth of the histogram [13-15].

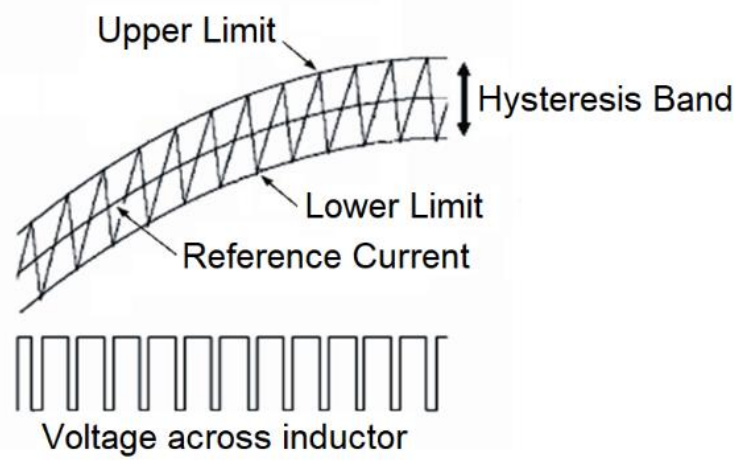

Figure 8. Hysteresis current band

\subsection{Battery charge controller}

The research used the principle of controlling the charge of the battery. Controlling the current and voltage across the capacitor via the charger control system $[16,17]$. A closed loop control system with PID method Ziegler-Nichols. The measuring current and output voltage from the Z-source DCDC converter circuit. The control both current and voltage at the capacitor (DC. Link). Controlling the charge of this battery can be divided into three levels. The one-step, control current and voltage. The bulk charge (constant current) absorption charge (constant voltage). The floating charge (constant voltage) based on the SOC principle (state of charge) and DOD (deep of discharge). The process of charging the battery starts by charging the battery in the first $40 \%$ of the $\%$ SOC. Moreover, using the bulk charge method as the initial charge of the charge cycle. Controlling the charge with a constant current starting at about $20 \%$ of the charge battery capacity (Ah). The causing the battery voltage not to reach the voltage gassing. The second step is to charge the remaining $20-30 \%$ of $\%$ SOC. Controlling the voltage by the absorption method. The charge causes the battery voltage to reach cyclic level voltage and depending on the type of battery. Moreover, the final step is to compensate for the $\% \mathrm{SOC}$ of the battery causing The SOC is equal to $100 \%$. The short floating period charges the voltage. That charges into the battery are approximately 13.4V, as shown in Figure 9. 


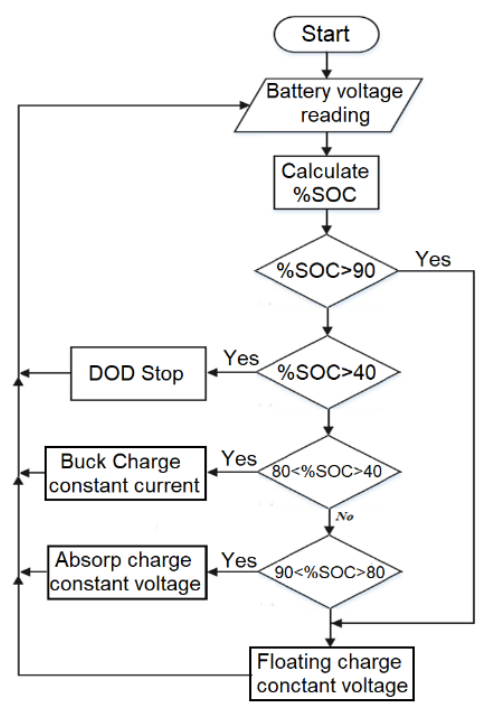

Figure 9. Flow chart operated battery charge controller

\section{RESULTS AND DISCUSSION}

The research results in this paper are divided into four parts. Consisting of the simulation results of the maximum tracking point of the proposed four methods. The second part tests the operation of Z-source DC-DC converter. The prototypes created in comparison to simulations. The fourth part, test the battery charge result of the prototype. Finally, testing the prototype of the whole system in the shrimp farm of the farmers. And collecting the satisfaction of farmers.

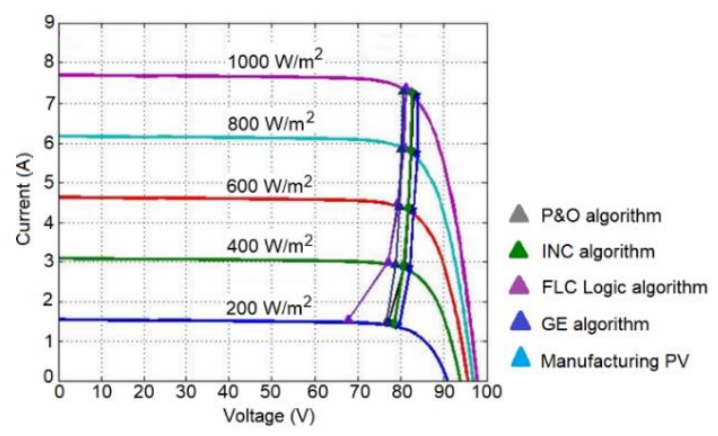

Figure 10. I-V characteristic of $\mathrm{P} \& \mathrm{O}, \mathrm{INC}, \mathrm{FLC}$ and GA algorithm

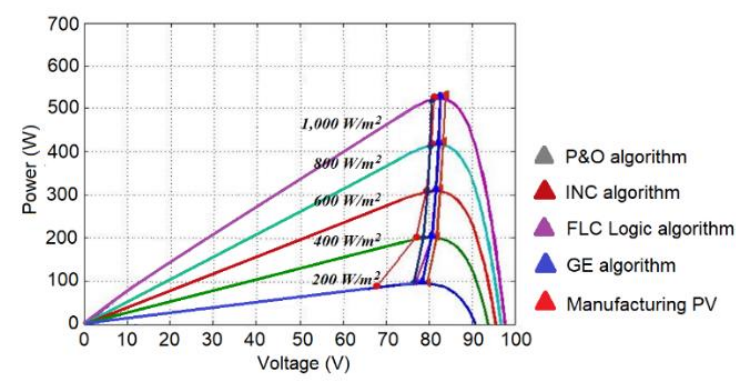

Figure 11. $P-V$ characteristic of maximum power point tracking

Figure 10 and Figure 11 show the algorithm in MATLAB/Simulink program. This will test for the relationship of $\mathrm{I}-\mathrm{V}$, it is found that the maximum power point tracking of every algorithm is consistent. As for the relationship of $\mathrm{P}-\mathrm{V}$, it was found that the maximum power point tracking of INC would work best when compared to other alkaloids. For this research, INC is used to control the maximum power point tracking provided to the $\mathrm{Z}$-source $\mathrm{DC}$ DC converter circuit.

Base on Figure 12, this research builds a prototype and test system performance, found that the Z-source DC-DC converter designed the device to the desired coordinates and simulated using MATLAB/Simulink can confirm its accuracy. Moreover, when the Z-source DC-DC converter is combined with the inverter, it can meet and control the voltage as needed. Figure 13, it found that when connected with an inverter, the harmonic distortion in the system has a total THD of $23.13 \%$. The result is a loss of the switch IGBT of the inverter.

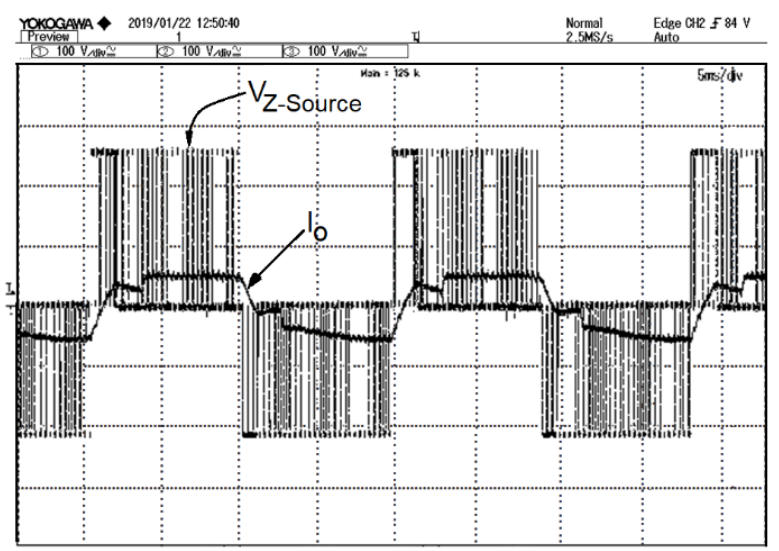

Figure 12. $V_{Z \text {-source }}$ and $I_{o}$ of mechanism

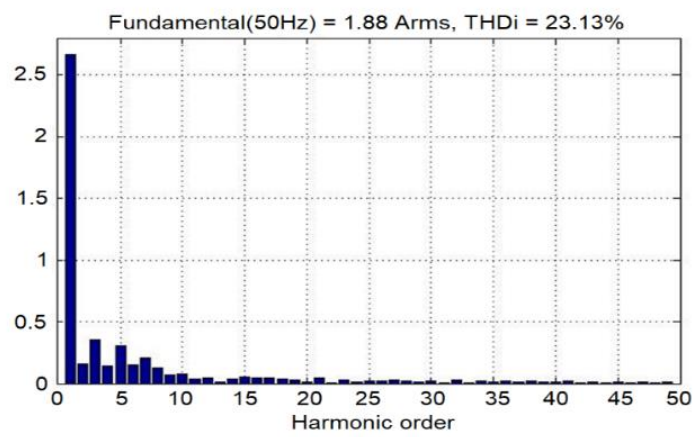

Figure 13. Harmonic spectrum of Z-source DC-DC converter

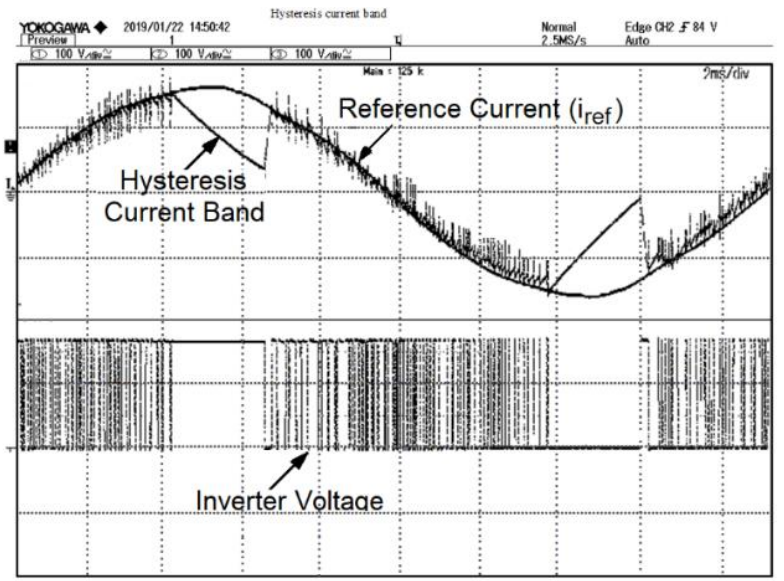

Figure 14. Hysteresis current band algorithm 
Based on Figure 14 for testing the operation of the hysteresis current band algorithm. For this prototype, the reference current $\left(i_{r e f}\right)$ is defined so that the hysteresis current band follows the sinusoidal reference according to the band up and band low. The results of PWM modulation are in accordance with the theory mentioned, can confirm that the proposed control principles work as intended.

Figure 15 from the power supply to the prototype to test the load current $\left(i_{L}\right)$ supplied to the aerator before installation in the shrimp ponds of farmers. It is found that the voltage and current that is released from the inverter when connected to the new aerator can supply the desired efficiency power. Base on Figure 16, from the supplied of voltage and current for the aeration device, it is found that the harmonic distortion in the system has a total THD of $21.63 \%$. The result of this harmonic distortion is also high, which is caused by the switch of the device of the inverter from the use of the current control principle of hysteresis. From the above principle, it is found that the detection of the current $\left(i_{L}\right)$ supplied to the aerator is compared to the current $\left(i_{\text {com }}\right)$ obtained from tracking the maximum power point of the solar cell to be the reference current $\left(i_{r e f}\right)$, which has a control hysteresis current control principle. Nevertheless, the prototype can still be improved so that the total harmonic distortion (THD) reduced by using PI control the hysteresis band to generate PWM signals for switch devices.

Charge energy from solar cells through the charge controller. When testing from 8:00 am to 4:00 pm in the clear sky climate of the shrimp farming ponds. The average light intensity is $794.89 \mathrm{~W} / \mathrm{m}^{2}$. The same time 1:00 pm, the solar cell stores the maximum power from the solar cell $37.79 \mathrm{~W}$. Because the solar cell receives the highest solar intensity. Moreover, it can find the average total power of $30.85 \mathrm{~W}$. as shown in Table 2.

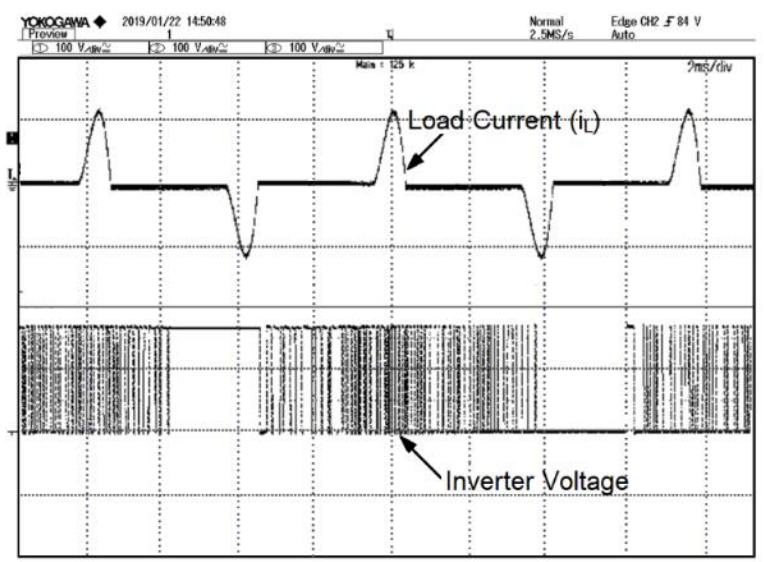

Figure 15. $i_{L}$ and voltage of the inverter

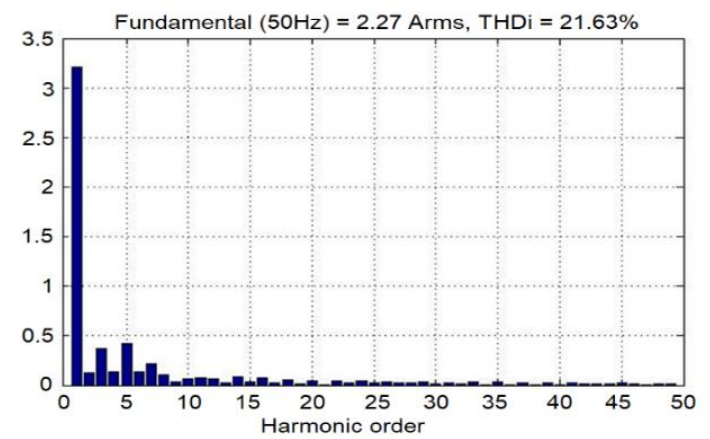

Figure 16. Harmonic spectrum of $i_{L}$ to aerator
Table 2. The test of the energy charge from the solar cells of the prototypes created

\begin{tabular}{ccccc}
\hline $\begin{array}{c}\text { Time } \\
\text { (hr.) }\end{array}$ & $\begin{array}{c}\text { Light } \\
\text { intensity } \\
\left(\mathbf{W} / \mathbf{m}^{2}\right)\end{array}$ & $\begin{array}{c}\text { Charge } \\
\text { voltage } \\
(\mathbf{V})\end{array}$ & $\begin{array}{c}\text { Charge } \\
\text { current } \\
(\mathbf{A})\end{array}$ & $\begin{array}{c}\text { MPPT } \\
\text { solar cells } \\
(\mathbf{W})\end{array}$ \\
\hline 8.00 & 315 & 18.09 & 0.69 & 12.42 \\
9.00 & 445 & 19.22 & 0.98 & 20.20 \\
10.00 & 722 & 20.10 & 1.35 & 21.45 \\
11.00 & 828 & 20.02 & 1.22 & 21.24 \\
12.00 & 877 & 20.75 & 1.67 & 22.42 \\
13.00 & 1167 & 21.11 & 1.79 & 37.79 \\
14.00 & 1020 & 21.12 & 1.69 & 35.69 \\
15.00 & 982 & 21.09 & 1.62 & 34.16 \\
16.00 & 798 & 20.12 & 1.43 & 28.77 \\
\hline
\end{tabular}

The installation of a prototype to aerator fill the air in the shrimp ponds of farmers. Found that the water in the shrimp ponds of farmers has increased oxygen. The measure energy efficiency of solar cells for 3 days in each pond of the farmers. It found that the work could continue for more than 8 hours per day. Test from 8:00 am and stop at $4.00 \mathrm{pm}$. The aerator works at a motor speed of $300 \mathrm{rpm}$. Power consumption while the motor is $36 \mathrm{~W}$. The measurement of oxygen in the water. The solar energy for aerator circulation of water in the shrimp ponds of the farmers. The compared to the use of solar energy for turbines originally. Testing as shown in Table 3.

Table 3 results of measuring oxygen content in water from shrimp farms of farmers using an oxygen meter (bante-820) when using a new aerator compared to the traditional aerator. It was found that the new aerators can produce more oxygen in the water between $8.00 \mathrm{am}$. $-16.00 \mathrm{pm}$. times than the traditional aerators. Consequently, can confirm that the amount of oxygen in the water is in the standard level (standard oxygen values in water in the maximum range 14.6 mmp. at $0^{\circ} \mathrm{C}$ and minimum $7 \mathrm{mmp}$. at $35^{\circ} \mathrm{C}$ under normal air pressure).

Table 3. Measurement of oxygen content in water for a period of 1 day

\begin{tabular}{ccc}
\hline $\begin{array}{c}\text { Time } \\
\text { (hours) }\end{array}$ & $\begin{array}{c}\text { New oxygen } \\
\text { aerator level } \\
\text { (ppm) }\end{array}$ & $\begin{array}{c}\text { Original oxygen } \\
\text { aerator level } \\
\text { (ppm) }\end{array}$ \\
\hline 8.00 & 2.45 & 2.06 \\
9.00 & 3.80 & 2.80 \\
10.00 & 4.65 & 2.95 \\
11.00 & 6.89 & 4.22 \\
12.00 & 8.33 & 4.93 \\
13.00 & 9.35 & 5.36 \\
14.00 & 10.26 & 6.89 \\
15.00 & 10.72 & 8.25 \\
16.00 & 10.89 & 9.48 \\
\hline
\end{tabular}

Responding to the satisfaction questionnaire on using solar energy as an aerator. They circulate water in shrimp ponds. The respondents are very satisfied with $(\bar{X}=3.56)$. Determined the satisfaction level found to be at the highest level. Reducing the steps and the installation period $(\bar{X}=4.69)$. The lowest level of satisfaction that is the suitability of the prototype installation ( $\bar{X}=1.42$ ). And another satisfaction is moderate.

\section{CONCLUSION}

The results, a prototype of an aerator that applied solar 
energy for shrimp pond farming. The test in Bang Pla Subdistrict, Bang Phli District, Samut Prakan Province, Thailand. It, the master aerator can work according to the specified objectives. The researcher tests the maximum power tracking of the principle P\&O, INC, FLC, and GA. Moreover, conditions supplied to Z-source DC-DC converter can be operated according to objectives. Considering, hysteresis current band algorithm control. It can be controlled inverter operate according to the specified objectives. And found that decreases total THD value. Testing the control of electric charge into the battery as designed. The circuit can operate according to the specified conditions. A prototype an aerator installed into the shrimp pond of the farmers. The check oxygen within the Shrimp pond. The oxygen values were below standards. Causing the pond shrimp in of the farmers to grow according to the standard. The inquiring about the satisfaction of the farmers uses the prototype. The farmers are satisfied with the good level, which is under the stated objectives. This research can make agriculture and society have more income, better domestic economy.

\section{ACKNOWLEDGEMENTS}

Dhonburi Rajabhat University, Thailand supported this event. The author would like to thank $\mathrm{Mr}$ Peerapong Chonlapan and Mr Sakdawut boontua for setting up the experiment to accomplish this research.

\section{REFERENCES}

[1] Michael B. New. (2002) Farming freshwater prawns: A manual for the culture of the giant river prawn (Macrobrachium rosenbergii). Food and Agriculture Organization of the United Nations, Rome, 16-48.

[2] Srichuai T. (2014). Energy in Thailand facts \& figures. Department of Alternative Energy Development and Efficiency Ministry of Energy, 1-8.

[3] Kerdchuen, T. (2013). Renewable energy in Thailand: Opportunity and technology allocation. Energy Procedia, 34: 13-16. https://doi.org/10.1016/j.egypro.2013.06.729

[4] Peerapong, P., Limmeechokchai, B. (2014). Investment incentive of grid connected solar photovoltaic power plant under proposed feed-in tariffs framework in Thailand. Energy Procedia, 52: 179-189. https://doi.org/10.1016/j.egypro.2014.07.069

[5] Chaianong, A., Pharino, C. (2015). Outlook and challenges for promoting solar photovoltaic rooftops in Thailand. Renewable and Sustainable Energy Reviews, 48: 356-372. https://doi.org/10.1016/j.rser.2015.04.042

[6] Potisat, T. (2017). Thailand solar PV policy. Fedral Ministry for Economic Affairs and Energy, 1: 1-6.

[7] Chaianong, A., Bangviwat, A., Menke, C., Darghouth, N.R. (2019). Cost-benefit analysis of rooftop PV systems on utilities and ratepayers in Thailand. Energies, 12(12): 2265. https://doi.org/10.3390/en12122265

[8] Hoppmann, J., Volland, J., Schmidt, T.S., Hoffmann, V.H. (2014). The economic viability of battery storage for residential solar photovoltaic systems-A review and a simulation model. Renewable and Sustainable Energy Reviews, 39: 1101-1118. https://doi.org/10.1016/j.rser.2014.07.068

[9] Kittner, N., Lill, F., Kammen, D.M. (2017). Energy storage deployment and innovation for the clean energy transition. Nature Energy, 2(9): 17125. http://doi.org/10.1038/nenergy.2017.125

[10] Reich, N.H., Mueller, B., Armbruster, A., Van Sark, W.G., Kiefer, K., Reise, C. (2012). Performance ratio revisited: is PR> 90\% realistic. Progress in Photovoltaics: Research and Applications, 20(6): 717-726. http://doi.org/10.1002/pip.1219

[11] Chaitanakulwat, A., Kinnares, V., Thungsuk, N. (2012). Single-phase grid-connected photovoltaic system with active power filter functionality. In 2012 15th International Conference on Electrical Machines and Systems (ICEMS). pp. 1-3.

[12] Fang, X. (2008). A novel Z-source dc-dc converter. In 2008 IEEE International Conference on Industrial Technology, $\mathrm{pp}$.

$1-4$. http://doi.org/10.1109/ICIT.2008.4608314

[13] Chaithanakulwat, A. (2019). Track the maximum power of a photovoltaic to control a cascade five-level inverter a single-phase grid-connected with a fuzzy logic control. International Journal of Power Electronics and Drive Systems, 10(4): 1863-1874. http://doi.org/10.11591/ijpeds.v10.i4

[14] Chaithanakulwat, A., Kinnares, V. (2017). Implementation of a low-cost single-phase gridconnected photovoltaic system with active power filtering mechanism. International Review of Electrical Engineering (IREE) Vil, 12: 175-182. https://doi.org/10.15866/iree.v12i2.11383

[15] Chaithanakulwat, A. (2019). Multi-functionality control, power filtering single-phase grid-connected photovoltaic system. American Journal of Electrical Power and Energy Systems, $\quad 8(2)$ : 62-70. http://doi.org/10.11648/j.epes.20190802.14

[16] Vieira, F.M., Moura, P.S., de Almeida, A.T. (2014). Energy storage system for self-consumption of photovoltaic energy in residential zero energy buildings. Renewable Energy, 103: 308-320. https://doi.org/10.1016/j.renene.2016.11.048

[17] Schmidt, O., Hawkes, A., Gambhir, A., Staffell, I. (2017). The future cost of electrical energy storage based on experience rates. Nature Energy, 2(8): 17110. http://doi.org/10.1038/nenergy.2017.110

\section{NOMENCLATURE}

$\begin{array}{ll}\text { PV } & \text { Photovoltaics module } \\ \text { P\&O } & \text { perturb and observe } \\ \text { INC } & \text { incremental conductance } \\ \text { FLC } & \text { fuzzy logic control } \\ \text { GA } & \text { Genetic algorithm } \\ \text { ppm } & \text { Oxygen unit } \\ \text { THD } & \text { Total harmonics distortion } \\ \text { SOC } & \text { State of charge } \\ \text { PWM } & \text { Pulse width modulation } \\ \text { PID } & \text { Proportional-Integral-Derivative Controller } \\ \text { MPPT } & \text { Maximum power point tracking } \\ \text { MPP } & \text { Maximum power point } \\ \text { ERC } & \text { Energy Regulatory Commission's } \\ \text { I } & \text { Electric current } \\ \text { V } & \text { Electric voltage } \\ \text { T } & \text { Temperature } \\ \text { IGBT } & \text { Isolate Gate Bipolar Transistor }\end{array}$


P Power of photovoltaic panel

D Non-linear diode

R Resistance

q Coulomb constant

k Temperature

A P-N junction ideality factor

$\mathrm{S} \quad$ Real solar radiation

C Coefficient

E Energy of the cell semiconductor

\section{Subscripts}

ph Photovoltaic

sh Parallel internal resistance

$s \quad$ Series initial resistance

ref Reference

ph,ref Photo reference

S,ref Saturation reference

$g$

Band-gap energy of the cell semiconductor 